\title{
PENGEMBANGAN PERANGKAT PEMBELAJARAN BERBASIS DISCOVERY BASED UNITY OF SCIENCES (DBUS) PADA MATERISISTEM REPRODUKSI KELAS XI SMA
}

\section{DEVELOPMENT OF DISCOVERY BASED UNITY OF SCIENCES (DBUS) LEARNING DEVICES IN REPRODUCTIVE SYSTEM SUBJECT FOR XI GRADE OF SMA}

\author{
Kiky Anggreini Priyanti ${ }^{1}$, Nur Khasanah ${ }^{2}$, Eka Vasia Anggis ${ }^{3}$ \\ ${ }^{1,2,3}$ Program Studi Pendidikan Biologi, Fakultas Sains dan Teknologi, UIN Walisongo Semarang \\ Email: kikyanggreini2799@gmail.com
}

\begin{abstract}
Abstrak: Perangkat pembelajaran berbasis Discovery Based Unity of Sciences (DBUS) menuntut siswa untuk dapat mencari, mengidentifikasi dan menemukan permasalahan yang ada di sekitar lingkungan siswa dengan tujuan untuk mengembangkan sikap spiritual dan melatih keterampilan siswa. Hal pertama yang dilakukan peneliti adalah melakukan analisis kebutuhan (need analysis) dengan mewawancarai guru biologi, menganalisis perangkat pembelajaran kelas XI semester genap dan membagikan angket kebutuhan siswa. Berdasarkan hasil wawancara dan analisis perangkat pembelajaran tersebut diperoleh data bahwa RPP yang digunakan belum terintegrasi kesatuan ilmu dan belum mengikuti SE nomor 14 tahun 2019 tentang penyederhanaan RPP, kemudian sikap spiritual dan keterampilan berpikir siswa masih rendah serta dalam proses penilaian dilakukan sepihak oleh guru, sehingga tidak ada evaluasi atau keterlibatan siswa. Berdasarkan permasalahan tersebut peneliti memberikan solusi untuk mengembangkan perangkat pembelajaran berbasis Discovery Based Unity of Sciences (DBUS) pada materi sistem reproduksi. Produk perangkat pembelajaran berupa RPP, LKPD dan instrumen self and peer assessment. Harapannya peserta didik mampu meningkatkan sikap spiritualnya dan mengembangkan kemampuan berpikir kritis. Penelitian ini menggunakan model pengembangan 4D (Define, Design, Development, dan Disseminate). Uji validitas dilakukan oleh ahli pendidikan, ahli materi, ahli media dan ahli integarsi nilai Islam. Hasil persentase RPP sebesar 89,23\%, LKPD 91,35\% dan instrumen self and peer assessment sebesar 88,53\%. Uji lapangan dilakukan dua kali uji, yaitu uji lapangan skala terbatas dan uji lapangan skala luas. Uji lapangan skala terbatas dilakukan oleh 5 peserta didik, untuk LKPD dan instrumen self and peer assessment memperoleh hasil kelayakan dengan persentase $85,6 \%$. Kemudian uji skala luas dilakukan oleh 30 peserta didik, untuk LKPD memperoleh hasilkelayakan dengan persentase $81,3 \%$ dan instrumen self and peer assessment memperoleh hasil kelayakan dengan persentase $81,2 \%$. Hasil dari pengembangan perangkat pembelajaran berbasis DBUS yaitu sangat layak digunakan dalam kegiatan pembelajaran.
\end{abstract}

Kata Kunci: perangkat pembelajaran, Discovery Based Unity of Sciences (DBUS), Sistem Reproduksi

\begin{abstract}
Discovery Based Unity of Sciences (DBUS) learning devices require students to be able to search, identify and find problems that exist around the student's environment with the aim of developing spiritual attitudes and training students' skills. The first thing that the researcher did was to conduct a needs analysis by interviewing biology teachers, analyzing learning tools for XI grade even semesters and distributing questionnaires to students' needs. Based on the results of interviews and analysis of learning tools, it was obtained data that the lesson plans used were not integrated with the unity of science and had not followed SE number 14 of 2019 concerning the simplification of lesson plans, then students' spiritual attitudes and thinking skills were still low and the assessment process was carried out unilaterally by the teacher, so it was not no evaluation or student involvement. Based on these problems, researchers provide solutions to develop learning tools based on Discovery Based Unity of Sciences (DBUS) on reproductive system materials. Learning device products in the form of lesson plans, LKPD and self and peer assessment instruments. It is hoped that students will be able to improve their spiritual attitudes and develop critical thinking skills. This study uses a 4D development model (Define, Design, Development, and Disseminate). The validity test was carried out by education experts, material experts, media experts and experts on the integration of Islamic values. The results of the percentage of RPP are $89.23 \%$, LKPD $91.35 \%$ and self and peer assessment instruments are $88.53 \%$. The field test was carried out twice, namely a limited-scale field test and a wide-scale field test. The limited scale field test was carried out by 5 students, for LKPD and self and peer assessment instruments the results obtained were feasibility with a percentage of $85.6 \%$. Then the wide-scale test was carried out by 30 students, for LKPD to obtain a feasibility result with a percentage of $81.3 \%$ and the self and peer assessment instrument to obtain a feasibility result with a percentage of $81.2 \%$. The results of the development of DBUS-based learning tools are very suitable for use in learning activities.
\end{abstract}

Keywords : learning tools, Discovery Based Unity of Sciences (DBUS), Reproductive System

\section{PENDAHULUAN}

Penilaian dan evaluasi dapat digunakan untuk melihat pengembangan laju pendidikan di Indonesia.
Programme for International Student Assesment (PISA) adalah suatu program yang menangani kebijakan dan praktik pendidikan. PISA membantu 
dalam memantau dan mengawasi perkembangan pengetahuan siswa [1]. PISA mampu memberikan gambaran hasil capaian siswa melalui pendidikan yang sedang ditempuh oleh suatu instansi sekolah. PISA sebagai alat evaluasi atau dasar sistem pendidikan agar pembangunan Sumber Daya Manusia (SDM) dapat ditingkatkan. Subjek penilaian PISA yaitu tes literasi yang meliputi membaca, matematika, dan sains [2]

Hasil penilaian PISA terhadap pendidikan berpengaruh besar terhadap kualitas Sumber Daya Manusia (SDM), karena pendidikan adalah kunci dalam membangun masa depan. Hal ini didukung dengan berkembangnya era revolusi industri 4.0 pada abad ke-18. Revolusi industri 4.0 yaitu segala sesuatu yang dihubungkan dengan teknologi dan semua mesin terhubung melalui sistem internet [3].

Indonesia adalah negara yang turut bersaing di era revolusi industri 4.0, maka pemerintah Indonesia memerlukan langkah untuk meningkatkan kemampuan dan keterampilan sumber daya manusia (SDM), salah satunya melalui bidang pendidikan. Peraturan Menteri Pendidikan Dan Kebudayaan (Permendikbud) Republik Indonesia Nomor 22 Tahun 2016 tentang Standar Proses Pendidikan Dasar dan Menengah menyebutkan :

"Proses pembelajaran pada satuan pendidikan diselenggarakan secara interaktif, inspiratif, menyenangkan, menantang, memotivasi peserta didik untuk berpartisipasi aktif, serta memberikan ruang yang cukup bagi prakarsa, kreativitas, dan kemandirian sesuai dengan bakat, minat, dan perkembangan fisik serta psikologis peserta didik. Untuk itu, setiap satuan Pendidikan melakukan perencanaan pembelajaran, pelaksanaan proses pembelajaran serta penilaian proses pembelajaran untuk meningkatkan efisiensi dan efektivitas ketercapaian kompetensi lulusan"

Surat Edaran (SE) nomor 14 tahun 2019 tentang penyederhanaan RPP yang dikeluarkan oleh Kementrian Pendidikan dan Kebudayaan (Kemendikbud), bahwa penyusunan RPP dilakukan dengan prinsip efisien, efktif dan berorientasi pada peserta didik. Kemudian 13 komponen yang telah diatur dalam Permendikbud nomor 22 tahun 2016 tentang standar proses hanya 3 komponen inti yang digunakan, yaitu tujuan pembelajaran, langkahlangkah (kegiatan pembelajaran) dan penilaian pembelajaran, selain itu komponen lainnya menajdi pelengkap. Hal ini bertujuan untuk mengembangkan kekreatifan guru dan berorientasi pada karakteristik peserta didik masing-masing.

Hasil wawancara yang dilakukan oleh penulis kepada guru Biologi Kelas XI di SMA N 9 Semarang bahwa guru mengacu pada Rencana Pelaksanaan Pembelajaran (RPP) yang telah disusun pada tahun 2018 dan digunakan sampai sekarang. Kemudian penulis menganalisis RPP yang digunakan guru, yaitu : 1). Alokasi waktu tidak sesuai dengan waktu kegiatan pembelajaran. Silabus untuk KD 3.13 dan 4.13 terdapat 8 Jam Pertemuan (8 JP), artinya bisa dilakukan 4 kali pertemuan dengan durasi 2 x 45 menit. sedangkan alokasi waktu di RPP tercatat 4 Jam dan hanya ada 1 kali pertemuan/kegiatan pembelajaran 2). Kegiatan awal bagian apersepsi dan motivasi belajar tidak dijelaskan secara rinci dan langsung pada kegiatan inti 3). IPK hanya berpusat pada materi ASI, sedangkan KD 3.13/4.13 terdapat pula materi teknologi sistem reproduksi dan kelainan/penyakit sistem reproduksi, namun tidak dibahas pada kegiatan pembelajaran 4). Kegiatan penutup tidak ada umpan balik dan penguatan karakter siswa untuk menanggapi kegiatan pembelajaran 5). RPP juga belum mengintegrasikan nilai Islam, tidak menerapkan konsep kesatuan ilmu dalam bentuk integrasi nilai karakter dan keislaman dengan nilai materi, sedangkan 90\% siswa SMAN 9 Semarang adalah beragama Islam.

Peneliti menganalisis perangkat pembelajaran selanjutnya yaitu LKPD, LKPD untuk sistem reproduksi belum disusun saat peneliti melakukan pra riset/observasi, oleh karena itu peneliti tidak bisa menganalisis LKPD yang digunakan guru. Kemudian guru belum memiliki instrumen penilaian secara tertulis sebagai pedoman penilaian siswa. Hasil wawancara dengan beberapa siswa kelas XI bahwa dalam proses penilaian guru tidak melibatkan siswa setiap tahapan proses penilaian, baik dalam menentukan tujuan belajar, penentuan tugas pembelajaran, pemantauan hasil, dan umpan balik untuk perbaikan pembelajaran, artinya proses penilaian masih berpusat pada guru (Teacher centered) serta tidak mampu memberikan informasi yang dibutuhkan guru dan siswa untuk memperbaiki proses pembelajaran.

Anggis [4] keterampilan kolaboratif antara guru dan siswa merupakan keterampilan yang menekankan pada tugas spesifik dan berbagi tugas dalam kerja kelompok, membandingkan kesimpulan dan prosedur kerja kelompok, dan memberikan keleluasaan yang lebih besar pada siswa dalam memahami materi.

Model pembelajaran Discovery Based Unity of Sciences (DBUS) sebagai hasil pengembangan model pembelajaran berbasis kesatuan ilmu yang dapat diimplementasikan pada kurikulum 2013. Melalui model DBUS siswa memperoleh pengalaman langsung yang dapat menambah kekuatan untuk menerima, menyimpan dan menerapkan konsep yang telah dipelajarinya serta kemampuan memecahkan masalah. Karakteristik model DBUS ini yaitu berorientasi pada pengembangan sikap spiritual siswa, namun juga mampu mengembangkan kompetensi sikap sosial, pengetahuan dan keterampilan yang merupakan tujuan kurikulum 2013 [5]. Model pembelajaran DBUS terfokus pada siswa (student centered) sehingga siswa berperan aktif dalam menemukan 
sebuah masalah, mengumpulkan berbagai masalah dan menemukan solusi berdasarkan permasalahan yang ditemukan [6]. Model pembelajaran Discovery Based Unity of Sciences (DBUS) memiliki langkahlangkah pembelajaran, diantaranya : 1) Stimulation using local wisdom, 2) Problem statement, 3) Observation and data collection, 4 ) Data processing 5) Verification base on religion 6) Implementation and awareness. Adanya kegiatan mengamati dalam proses pembelajaran, siswa dapat bekerja sama dan saling bertukar argumen untuk memecahkan suatu masalah yang dapat menigkatkan rasa keingintahuansiswa [7].

KD 3.13 dan 4.13 materi sistem reproduksi memerlukan sebuah aktivitas untuk mencari, mengidentifikasi, dan memecahkan masalah yang didapatkan dari lingkungan sekitar siswa serta menumbuhkan sikap spiritual dan sosial. Hasil wawancara guru dan angket kebutuhan siswa, 70\% siswa menganggap materi sistem reproduksi sulit dipahami dan siswa sulit memahami materi yang tidak diimplemetasikan kedalam kehidupan seharihari. Kemudian materi sistem reproduksi sangat tepat dan mudah diimplementasikan kehidupan sehari-hari. Sehingga DBUS merupakan model pembelajaran yang tepat untuk materi sistem reproduksi. Peserta didik diharapkan termotivasi untuk belajar biologi, menemukan masalah dan mampu memberikan solusi berdasarkan kegiatan pengamatan dan konsep yang telah dipelajarinya [8]. Anggis [9] menambahkan bahwa dalam kegiatan pembelajaram siswa tidak langsung menerima konsep yang disampaikan guru, tetapi dilatih untuk merangsang dan menemukan pengetahuan baru berdasarkan pengamatan atau observasi lingkungan sehingga siswa dapat mengimplementasikan materi langsung di kehidupan serta proses belajar lebih menarik.

Rumusan masalah penelitian adalah bagaimana karakteristik dan kelayakan perangkat pembelajaran berbasis Discovery Based Unity of Sciences (DBUS) pada materi sistem reproduksi kelas XI SMA. Penelitian ini bertujuan untuk menjelaskan karakteristik dan kelayakan pengembangan perangkat pembelajaran berbasis Discovery Based Unity of Sciences (DBUS) pada materi sistem reproduksi kelas XI.

\section{METODE PENELITIAN}

Jenis penelitian yang digunakan adalah Research and Development $(\mathrm{RnD})$ yaitu suatu proses atau tahapan yang digunakan untuk mengembangkan dan memvalidasi suatu produk yang dihasikan [10]. Tujuan penelitian $\mathrm{RnD}$ adalah menghasilkan produk penelitian untuk mengembangkan kualitas pendidikan dan pembelajaran secara efektif. Model pengembangan yang digunakan adalah 4D yang terdiri dari empat tahapan, yaitu Define (pendefinisian), Design (perancangan), Development (pengembangan) dan Disseminate (penyebaran). Penulis memilih model 4D dengan pertimbangan dari penelitian [11], hasil penelitian menunjukkan bahwa model 4-D memiliki kesesuaian dengan pengembangan perangkat pembelajaran biologi, yaitu langkah-langkah pengembangannya jelas dan sistematis sehinggamenuntun langkah penulis dalam menyelesaikan produk akhir yang akan dihasilkan, kemudian prosedur pengembangan ini relevan dengan prinsip pengembangan perangkat pembelajaran serta memerlukan waktu yang tidak lama dalam melakukan penelitian, namun hasil yang diperoleh bisa maksimal.

Penelitian ini menggunakan instrumen yang diuji oleh ahli materi, ahli pendidikan, ahli media dan guru Biologi. Ahli Pendidikan merupakan dosen yang menguasi sistematika dan prinsip penyusunan perangkat pembelajaran, ahli materi merupakan dosen yang menguasai materi biologi bidang Sistem Reproduksi, ahli integrasi nilai Islam merupakan dosen yang menguasai bidang pengintegrasian kesatuan ilmu agama dengan ilmu sains, ahli media Merupakan dosen yang menguasai pada tampilan perangkat pembelajaran (LKPD dan instrument penilaian) secara visual, meliputi bahasa, desain, dan ketertarikan perangkat pembelajaran, Guru Biologi SMA Guru yang mengampu mata pelajaran biologi kelas XI di SMA N 9 Semarang, peserta didik kelas XI Responden peserta didik yaitu siswa kelas XI MIPA 7 SMA N 9 Semarang, 5 siswa untuk uji coba skala terbatas dan 30 siswa uji coba skala luas perangkat pembelajaran yang dikembangkan.

Penelitian ini menggunakan teknik pengumpulan data, diantaranya yaitu wawancara, angket/kuesioner, observasi dan dokumentasi. Jenis data pada penelitian ini terdiri dari data kuantitatif dan data kualitatif. Data kuantitatif berupa hasil skor perangkat pembelajaran dan instrumen penelitian sedangkan data kualitatif berupa saran validator dan praktisi lapangan terhadap perangkat pembelajaran yang dikembangkan. Langkah-langkah yang digunakan peneliti dalam mengolah data hasil validasi dan hasil uji coba lapangan adalah 1) Analisis kebutuhan perangkat pembelajaran DBUS Data mengenai kebutuhan perangkat pembelajaran DBUS diperoleh dengan melakukan wawancara kepada guru dan siswa serta menyebarkan angket kebutuhan siswa kelas XI SMA N 9 Semarang.

Hasil wawancara dianalisis secara deskriptif kualitatif dan hasil angket kebutuhan siswa dianalisis secara kuantitatif [12]. 2) Analisis kevalidan produk Uji kevalidan/kelayakan produk dilakukan oleh validator (ahli Pendidikan, ahli materi, ahli media dan ahli integrase nilai Islam) serta guru Biologi dan siswa SMA N 9 Semarang melalui angket penilaian yang sudah disediakan oleh peneliti. Penskoran dalam angket ini menggunakan skala likert, dengan menggunakan beberapa butir pertanyaan untuk mengukur perilaku individu dengan merespon lima pilihan pada setiap butir pernyataan [13]. Berikut ini kriteria skor penilaiannya: 
$\underline{\text { Tabel 1. Kriteria Skor Penilaian Kriteria Skor }}$

\begin{tabular}{cc}
\hline Kriteria & Skor \\
\hline Sangat baik & 5 \\
\hline Baik & 4 \\
\hline Cukup baik & 3 \\
\hline Tidak baik & 2 \\
\hline Sangat tidak baik & 1 \\
\hline (Sumber : Sugiyono, 2016)
\end{tabular}

Data yang dianalisis dalam penelitian ini meliputi analisis kevalidan perangkat pembelajaran berbasis DBUS. Hal ini dapat dilakukan dengan cara : a) Tabulasi semua data yang diperoleh untuk setiap aspek penilaian, sub aspek dan butir penilaian instrumen dari setiap penilai. b) Menghitung rata-rata skor Setelah mendapatkan hasil validasi dari para ahli untuk kevalidan instrumen dan produk perangkat pembelajaran (RPP, LKPD, dan Instrumen penilaian), menurut Akbar (2013) kriteria validitas dalam pengambilan keputusan revisi produk perangkat pembelajaran c) Menghitung rata-rata skor menjadi nilai kategori.

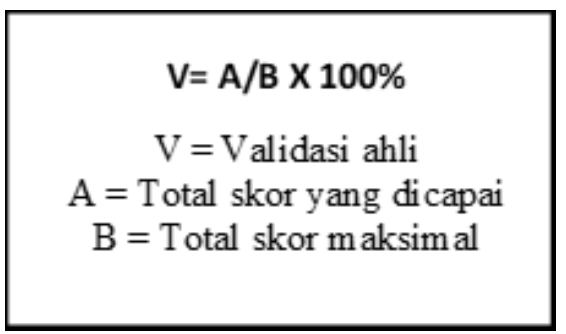

Setelah didapatkan hasil perhitungan persentase masing-masing produk, maka dilakukan pengambilan keputusan untuk merevisi instrumen dan perangkat pembelajaran dengan kriteria validitas yang tertera pada tabel berikut ini :

Tabel 2. : Kriteria Validitas Produk Perangkat Pembelajaran

\begin{tabular}{ccc}
\hline $\begin{array}{c}\text { Tingkat } \\
\text { Pencapaian }\end{array}$ & Kriteria & $\begin{array}{c}\text { Keterangan Tindak } \\
\text { Lanjut }\end{array}$ \\
\hline $81 \%-100 \%$ & $\begin{array}{c}\text { Sangat } \\
\text { valid }\end{array}$ & $\begin{array}{c}\text { Layak atau dapat } \\
\text { digunakan tanpa } \\
\text { revisi }\end{array}$ \\
\hline $61 \%-80 \%$ & Valid & $\begin{array}{c}\text { Dapat digunakan, } \\
\text { namun perlu direvisi } \\
\text { kecil }\end{array}$ \\
\hline $41 \%-60 \%$ & $\begin{array}{c}\text { Kurang } \\
\text { valid }\end{array}$ & $\begin{array}{c}\text { Disarankan tidak } \\
\text { dipergunakan } \\
\text { karenaperlu direvisi } \\
\text { besar }\end{array}$ \\
\hline $21 \%-40 \%$ & $\begin{array}{c}\text { Tidak } \\
\text { valid }\end{array}$ & $\begin{array}{c}\text { Tidak boleh } \\
\text { dipergunakan }\end{array}$ \\
\hline $0 \%-20 \%$ & $\begin{array}{c}\text { Sangat } \\
\text { tidak } \\
\text { valid }\end{array}$ & $\begin{array}{c}\text { Tidak boleh } \\
\text { dipergunakan }\end{array}$ \\
\hline
\end{tabular}

(Sumber : Akbar, 2013)
Secara keseluruhan, teknik analisis data penelitian ini dapat dilihat pada tabel berikut:

Tabel 3.Teknik Analisis Data

\begin{tabular}{cccc}
\hline \multirow{2}{*}{ Tahap } & $\begin{array}{c}\text { Teknik } \\
\text { Pengumpula } \\
\text { n Data }\end{array}$ & $\begin{array}{c}\text { Jenis } \\
\text { Data }\end{array}$ & Analisis \\
& $\begin{array}{c}\text { Wawancara } \\
\text { dan } \\
\text { observasi }\end{array}$ & Kualitatif & Deskriptif \\
\cline { 2 - 4 } Define & $\begin{array}{c}\text { Angket } \\
\text { kebutuhan } \\
\text { siswa }\end{array}$ & Kuantitatif & Statistik \\
& $\begin{array}{c}\text { Desain } \\
\text { tampilan } \\
\text { produk }\end{array}$ & Kualitatif & Deskripstif \\
\hline Devign & & \\
\hline
\end{tabular}

\section{HASIL DAN PEMBAHASAN}

Penelitian pengembangan ini terdiri dari tiga tahapan, yaitu define, design dan develop. Tahap define terdiri dari lima langkah pokok yaitu analisis ujung depan, analisis siswa, analisis tugas, analisis konsep dan perumusan tujuan pembelajaran. Tahapan pertama ,yaitu define. Hasil tahapan define, bahwa pembelajaran kelas XI SMA N 9 Semarang tahun ajaran 2019/2020 menggunakan kurikulum 2013.

Kemudian pembelajaran Biologi yang diajarkan oleh guru belum diintegrasikan dengan permasalahan keislaman, kurang mengimplementasikan dalam kehidupan sehari-hari dan kurang mampu meningkatkan keterampilan berpikir kritis dan aspek spiritual siswa. Kemudian, $70 \%$ siswa beranggapan materi sistem reproduksi sulit dipahami, siswa beranggapan dalam proses penilaian guru tidak menilai dengan adil, siswa tidak ikut serta dalam proses penilaian. Berdasarkan pendefinisian masalah diatas dikembangkan sebuah perangkat pembelajaran yang dibuat untuk meningkatkan keterampilan berpikir kritis dan aspek spiritual siswa serta teknik penilaian yang melibatkan siswa.

Tahapan yang kedua, yaitu design. Peneliti menentukan media yang akan digunakan, pemilihan format dan membuat rancangan awal (prototype). Tahapan design ini menghasilkan draft I prototype perangkat pembelajaran yang dikembangkan.

Tahapan yang ketiga, yaitu develop. Setelah menghasilkan draft I, draft I diuji oleh beberapa validator untuk menilai kelayakan produk. Validator yang menilai terdiri dari ahli pendidikan, ahli materi, ahli media, ahli integrasi Islam. Perangkat pembelajaran yang dikembangkan meliputi RPP, LKPD dan instrumen penilaian diuji oleh empat validator ahli, apabila skor keempat validator diratarata maka perangkat pembelajaran yang dikembangkan termasuk dalam kategori sangat baik dengan presentase secara berturut-turut adalah $89,23 \%, 91,35 \%$ dan $88,53 \%$. 


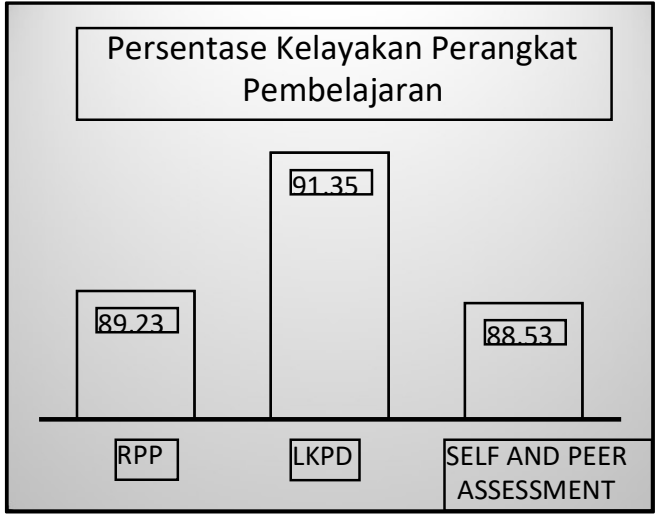

Gambar 1 Grafik Hasil Uji Kelayakan Perangkat

Tahapan selanjutnya yaitu uji coba produk. Uji coba produk bertujuan untuk mengetahui kelayakan perangkat pembelajaran. Kelayakan perangkat pembelajaran diperoleh dari hasil angket respon siswa dan angket kelayakan guru. Hasil respon siswa untuk LKPD memperoleh persentase sebesar $81,3 \%$ yang termasuk dalam kategori sangat layak dan instrumen penilaian sebesar $81,2 \%$ yang termasuk dalam kategori sangat layak. Kemudian skor kelayakan guru untuk RPP memperoleh persentase sebesar $100 \%$ yang termasuk dalam kategori sangat layak, LKPD sebesar 98,3\% yang termasuk dalam kategori sangat layak dan instrumen penilaian sebesar $100 \%$ yang termasuk dalam kategori sangat layak sehingga perangkat pembelajaran dinyatakan sangat layak apabila digunakan dalam kegiatan pembelajaran.

\section{Persentase Hasil Uji Coba Produk}

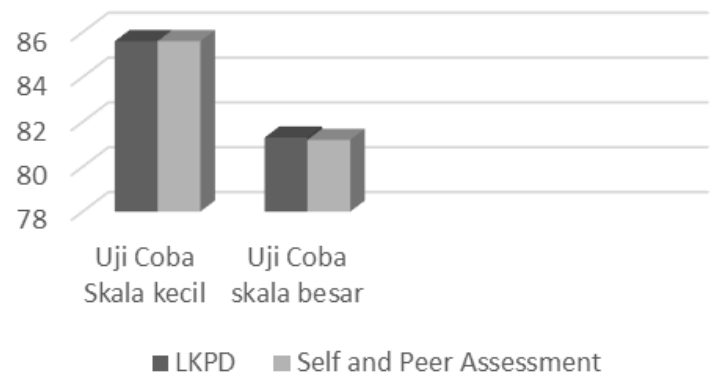

Gambar 2. Hasil Uji Coba Lapangan

\section{KESIMPULAN}

Berdasarkan hasil penelitian pengembangan perangkat pembelajaran berbasis Discovery Based Unity of Sciences (DBUS) pada kelas XI SMA N 9 Semarang dapat disimpulkan bahwa Perangkat pembelajaran berbasis DBUS pada kelas XI SMA N 9 Semarang sangat layak digunakan dalam kegiatan pembelajaran. Hal tersebut dapat diketahui dari hasil uji kelayakan oleh para ahli, yaitu untuk RPP mendapat presentase sebesar 89,23\%, untuk LKPD mendapat nilai presentase sebesar 91,35\% dan instrumen self and peer assessment mendapat nilai presentase sebesar $88,53 \%$. Kemudian hasil uji lapangan skala terbatas dilakukan kepada 5 peserta didik, untukLKPD memperoleh presentase sebesar $85.6 \%$ dan instrumen self and peer assessment memperoleh presentases sebesar 85,6\%. Kemudian untuk uji lapangan skala luas dilakukan kepada 30 peserta didik, untuk LKPD memperoleh presentase sebesar $81,3 \%$ dan untuk instrumen self and peer assessmentmemperoleh presentase sebesar $81,2 \%$.

\section{DAFTAR PUSTAKA}

[1]. Pratiwi, Indah. 2019. Efek Program PISA Terhadap Kurikulum Di Indonesia. Jakarta : Pusat Penelitian Kebijakan Pendidikan dan Kebudayaan

[2]. Khairuddin. 2017. PISA, Uji Coba Soal Pisa Dan Strategi Siswa Menjawab Soal. Medan : Universitas Negeri Medan

[3]. Syamsuar dan Reflianto.2019. Pendidikan Dan Tantangan Pembelajaran Berbasis Teknologi Informasi Di Era Revolusi Industri 4.0. Padang : Universitas Negeri Padang

[4]. Anggis, Eka Vasia. 2020. Model Group Investigatiom Untuk Meningkatkan Minat Belajar Siswa SMP. Bioeduca : Jurnal Pendidikan Biologi. 02 (1) : 56-60

[5]. Khasanah, Nur. 2016. SR (Science and Religion) Sebagai Pendekatan Pembelajaran Biologi Pada Kurikulum 2013 Untuk Meningkatkan Karakter Siswa. Biodidaktika, $11(2): 45-52$

[6]. Khasanah, Nur.2016. The Influence of Guided Discovery Learning Model Toward Scientific Literacy Based on Natualist Intelligence. Proceeding Biology Education Conference. 13 (1) : 346-351

[7]. Anggis, Eka Vasia. 2017. Technical Arrangement of Excretion System by Problem Based Learning Model of Senior High School. Proceeding Biology Education Conference. 13 (1) : 455-458

[8]. Khasanah, Nur. 2018. Memberdayakan Hight Order Thinking Skills (HOTS) Melalui Model Discovery Based Unity of Sciences (DBUS). Semarang. Phenomenon. 08 (2) : 215-224

[9]. Anggis, Eka Vasia. 2016. Penerapan Model Kooperatif JIGSAW berbasis Lesson Study untuk Meningkatkan Keterampilan Kolaboratif dan Hasil Belajar Kogntif. Proceeding Biology Educatio Conference. 13 (1) : 493-497

[10]. Sugiyono. 2016. Metode Penelitian (Kuantitatif, Kualitatif, dan $R \& D)$ ). Bandung : Penerbit Alfabeta

[11]. Aida, Nur dkk. 2016. Pengembangan Perangkat Pembelajaran Biologi Berbasis Inkuiri Pada Materi Sistem Ekskresi Untuk Kelas XI SMA Negeri 10 Bulukumba. Jurnal Bionature. 17 (2) : 114-123

[12]. Akbar, S. 2013. Instrumen Perangkat pembelajaran. Bandung : PT.Remaja 
Jurnal Inovasi Pendidikan dan Sains

Vol. 2 No. 3, Desember 2021 : 82-87

ISSN 2721-9119 (Online)

Rosdakarya

[13]. Budiaji, Weksi. 2013. Skala Pengkuran dan Jumlah Respon Skala Likert. Jurnal Ilmu

Pertanian dan Perikanan. 2 (2) ; 127-133 